\title{
The Effects of Foreign Language Anxiety and Test Anxiety on Foreign Language Test Performance
}

\author{
Masoomeh Salehi \\ Islamic Azad University, Shahr-e-Qods branch, Iran \\ Fahimeh Marefat \\ Allameh Tabatabaee University, Iran
}

\begin{abstract}
This study aimed at investigating the effects of foreign language anxiety and test anxiety on foreign language test performance. Another purpose of this study was to see whether there is any relationship between foreign language anxiety and test anxiety. Two hundred students of English as a foreign language at preintermediate (Pre 1) level participated in this study. In the present study, the Foreign Language Classroom Anxiety Scale and the Test Anxiety Scale were used to measure foreign language anxiety and test anxiety, respectively. The scores obtained in each questionnaire were correlated with the students' final exam grades. Both foreign language anxiety and test anxiety had a statistically significant negative correlation with the exam grades, suggesting that both types of anxiety have debilitative effects on test performance. Correlation analyses indicated a strong positive relationship between foreign language anxiety and test anxiety. Therefore, English teachers are recommended to try to reduce both language anxiety and test anxiety by creating a friendly and supportive atmosphere in class, encouraging students' involvement in class activities, and teaching some anxiety-reducing strategies to the students.
\end{abstract}

Index Terms - foreign language anxiety, test anxiety, test performance

\section{INTRODUCTION}

In current research in EFL, a great deal of effort has been devoted to establishing the role of psychological factors in the success or failure of the learners. Among these psychological factors are affective factors with "anxiety" as one of their sub-categories. There are two general types of anxiety. One of them is called trait anxiety and is defined as "a relatively stable tendency to exhibit anxiety in a large variety of circumstances" (Phillips, 1992, p. 14). Another type of anxiety is state anxiety, which is defined as "a situation-specific trait anxiety; that is, an individual suffering from state anxiety will manifest a stable tendency to exhibit anxiety but only in certain situations" (Phillips, 1992, p. 14).

Trait anxiety, because of its global and somewhat ambiguously defined nature, has not proved to be useful in predicting second language achievement (MacIntyre \&Gardner, 1991). According to Brown (2000), language anxiety is a kind of state anxiety, and Phillips (1992) thinks that a well-known type of state anxiety is test anxiety. Horwitz, Horwitz and Cope (1986) considered language anxiety as distinct from general anxiety and identified three components of foreign language anxiety:

1. communication apprehension, arising from learners' inability to adequately express mature thoughts and ideas;

2. fear of negative social evaluation, arising from a learner's need to make a positive social impression on others; and

3. test anxiety, or apprehension over academic evaluation.

They developed their Foreign Language Classroom Anxiety Scale (FLCAS) based on these three components. However, for test anxiety, they just considered foreign language test anxiety.

MacIntyre and Gardner (1989) and Aida (1994) analyzed Horwitz et al.'s (1986) FLCAS by factor analysis. Both of these studies supported their idea that language anxiety has the first two above-mentioned components. However, they did not support Horwitz et al.'s (1986) claim that test anxiety is the third component of foreign language anxiety.

Considering test anxiety, In'nami (2006) studied the effects of test anxiety on listening test performance. The results of In'nami's study showed that none of the factors of test anxiety (i.e., general test worry, test-irrelevant thinking, and emotion) affects listening test performance. This finding is in line with Aida (1994) and MacIntyre and Gardner (1989) who say that test anxiety is an anxiety problem in general and is not specifically related to the foreign language learning context.

If we consider test anxiety to be separate from foreign language anxiety, their effects on foreign language test performance can be investigated separately. In fact, this is what is done in the present study. In the EFL literature, there are several studies which investigate the relationship between foreign language anxiety and foreign language proficiency or performance (e.g. Aida, 1994; Matsuda \& Gobel 2004; Phillips, 1992) or the relationship between 
foreign language anxiety and one or more language skills (e.g. Cheng, Horwitz, \& Schallert, 1999; Elkhafaifi, 2005; Matsuda \& Gobel 2001; Mills, Pajares, \& Herron, 2006; Saito, Garza, \& Horwitz, 1999).

The studies investigating the relationship between test anxiety and foreign language test performance are fewer. Some of these studies have investigated the relationship between test anxiety and foreign language test performance in general (Chastain, 1975; Horwitz, 1986) and some others have investigated the relationship between test anxiety and test of a language skill or language component (In'nami, 2006; MacIntyre \& Gardner, 1989).

All these studies have focused on either foreign language anxiety or test anxiety. What is lacking in the literature is a study which investigates both of these types of anxiety and compares their effects on foreign language test performance. Administering both types of questionnaires in one study enjoys two advantages: first, we can compare their effects on foreign language test performance to see the effects of which one is more prominent. Second, we can see whether there exists any relationship between these two types of anxiety or not.

The only study which has investigated foreign language anxiety and test anxiety at the same time is the study of MacIntyre and Gardner (1989). But in their study, they used only ten items of the Test Anxiety Scale, and they used a foreign language scale other than FLCAS. Furthermore, MacIntyre and Gardner (1989) themselves referred to contradictory (both negative and positive) effects of test anxiety on language course grades (Chastain, 1975; Horwitz, 1986) and said, " a closer examination of the role of test anxiety in the foreign language classroom seems warranted" (p. 269).

Therefore, the purpose of the study is to investigate the effects of foreign language anxiety and test anxiety on foreign language test performance and to see which one is more effective in this concern. We also want to see whether there is any relationship between these two types of anxiety themselves.

\section{REVIEW OF LITERATURE}

In several studies (e.g. Aida, 1994; Elkhafaifi, 2005; Philips, 1992; Steinberg \& Horwitz, 1986), anxiety was found to have a negative relationship with language performance. In fact it was a debilitative anxiety. But we also have facilitative anxiety. There is some concern or some apprehension over the task to be accomplished which prevents the learner from being wishy-washy (Brown, 2000). In some studies, anxiety has shown to be facilitative (Baily, 1983; Kleinmann, 1977; MacIntyre \& Gardner, 1994; Tobias, 1986).

Horwitz (1990) believes that in the language learning environment, there is no such thing as facilitative anxiety; all anxiety in that environment is likely to be debilitative. However, in the study of Oxford and Ehrman (1995), which shows the relationships between language learning strategies and several other factors such as anxiety, it was found that self-reported anxiety about speaking the language in class has a positive relationship with cognitive strategy use. So it confirms Brown's (2000) view that facilitative anxiety exists, too.

MacIntyre and Gardner (1989) referred to such contradictory results obtained in previous studies. They point out that most of these contradictory studies measured trait or state anxiety which is applicable across several situations, but this may not be the best way to measure anxiety in a language learning context. Gardner (1985) has proposed that scales which are directly concerned with foreign language anxiety are more appropriate for studying language anxiety than general anxiety scales.

Such a scale was developed by Horwitz et al. (1986) who believe that language anxiety is distinct from general anxiety. They defined language anxiety as "a distinct complex of self-perceptions, beliefs, feelings, and behaviors related to classroom language learning arising from the uniqueness of the language learning processes" (p. 128).

Horwitz et al. (1986) describe three components of foreign language anxiety: communication apprehension, fear of negative social evaluation, and test anxiety. Horwitz et al. believe that these three components have deleterious effect on second language acquisition. Horwitz (1986) reported that the FLCAS had a correlation coefficient of $r=0.28(\mathrm{p}=$ $0.063, \mathrm{n}=44$ ) with communication apprehension (measured by McCroskey's (1970) personal report of communication apprehension), $\mathrm{r}=0.53(\mathrm{p}<0.01, \mathrm{n}=60)$ with test anxiety (measured by Sarason's (1978) Test Anxiety Scale), and $\mathrm{r}=$ $0.36(\mathrm{p}<0.01, \mathrm{n}=56)$ with fear of negative evaluation (measured by Watson and Friend's (1992) fear of negative evaluation scale).

Horwitz et al. (1986) tested their theory on 75 English learners of Spanish at an American university. The study revealed that significant foreign language anxiety was experienced by many students in foreign language learning which adversely affected their performance at that language.

Aida (1994) also examined the effects of anxiety on foreign language performance. His study showed that language anxiety was negatively correlated to students' performance in Japanese as a foreign language.

Phillips (1992) investigated the relationship between language anxiety and students' oral test performance. The measure for language anxiety in this study was FLCAS (Horwitz et al, 1986). Phillips measured the correlation between language anxiety and oral test performance and found that there was a moderate negative relationship between them.

More recently, Liu and Jackson (2008) investigated the unwillingness to communicate and anxiety of Chinese learners of English as a foreign language. Their results revealed that most of their participants were willing to participate in interpersonal conversations, but they did not like risk using/speaking English in class. In addition, more than one third of them felt anxious in their English language classrooms. The participants' unwillingness to 
communicate and their foreign language anxiety correlated with each other and with their own rating of their English proficiency.

In a large scale study of multilingual adults around the world, Dewaele, Petrides, and Furnham (2008) found that individuals who were younger when they started learning a second or third language had lower levels of language anxiety. Lower anxiety levels were also associated with knowledge of more languages and higher levels of Emotional Intelligence. In spite of most previous studies, this article has examined language learners who are successful and who use language outside the classroom. This study suggests that in addition to individual characteristics, larger social circumstances such as the availability of supportive conversional partners and L2 role models may have a role in reducing language anxiety.

Marcos-Llinás and Garau (2009) investigated the effects of language anxiety on course achievement in three foreign language proficiency levels of Spanish, namely, beginner, intermediate, and advanced. Using FLCAS (Horwitz et al., 1986), they showed that advanced learners showed higher levels of anxiety in comparison with beginner and intermediate participants. They also found language anxiety to be negatively related to foreign language classroom achievement. They also found that female students were less anxious than male ones. (For overviews of foreign language anxiety see Horwitz, 2010; Zheng, 2008).

Although research into foreign language anxiety is abundant, few investigations have directly focused on test anxiety, which is defined as a "special case of general anxiety consisting of phenomenological, physiological, and behavioral responses related to a fear of failure and to experience of evaluation or testing" (Sieber, 1980, pp. 17-18). Among these few studies is Chastain's (1975) in which test anxiety was negatively and moderately correlated with course grades in beginner-level, French audiolingual classes, whereas test anxiety was positively and very weakly correlated in beginnerlevel, regular French classes $(r=0.18)$ and test anxiety was positively and weakly correlated in beginner-level, regular German and Spanish classes. In another study by Horwitz (1986), test anxiety had a negative and very weak relationship with final grades in the case of introductory-level, foreign language students.

Joy (2013) examined the level of test anxiety related to pre-, during-, and post-test stages of second language learners. The results showed that the most anxiety-provoking stage was during-test stage, followed by the pre-test stage. The least anxiety-provoking stage was the post-test stage. Surprisingly, all of the participants of this study reported that teachers had not helped them to cope with test anxiety.

Since most of the studies concerning anxiety and foreign language learning are correlational in nature, it is difficult to distinguish the causality of this relationship. Some scholars believe that it is poor performance which leads to higher anxiety (MacIntyre and Gardner, 1989; MacIntyre and Gardner, 1994). Others believe that anxiety is a cause of poor performance rather than its consequence (Elkhafaifi, 2005; MacIntyre, 1995; Matsuda and Gobel's, 2004).

Based on the inconclusive results obtained in previous studies, more research seems to be needed in this area. Moreover, it is worth comparing the effects of foreign language anxiety and test anxiety on foreign language test performance because it helps foreign language teachers know which type of anxiety they should try to reduce more than the other one. This study was conducted to fill this gap. To be more specific, the research questions of this study are stated in the following section.

\section{RESEARCH QUESTIONS}

Three main research questions are addressed in this study:

1. Is there any relationship between foreign language anxiety and foreign language test performance?

2. Is there any relationship between test anxiety and foreign language test performance?

3. Is there any relationship between language anxiety and test anxiety?

\section{METHOD}

\section{A. Participants}

The participants of this study were 200 students of English as a foreign language at Iran Language Institute (ILI), Karaj Branch. To make sure that differing levels of language proficiency would not affect the results of the test, the students at the same level were chosen. The participants of this study were all at the level of Pre-intermediate 1 (henceforth Pre 1), which is the sixth level of adult courses at the ILI. Since only a few male students (7 students) cooperated with the researchers, the majority of participants were female (193 students). The age of the participants ranged from 14 to 47 . The average age of the participants was 19.

\section{B. Instrumentation}

Two questionnaires were used in this study. One of them measured foreign language anxiety and the other one measured test anxiety.

1. Foreign Language Classroom Anxiety Scale

The first questionnaire is called Foreign Language Classroom Anxiety Scale (FLCAS) developed by Horwitz et al. (1986). It is a 33-item, five-point Likert scale questionnaire. The answers to each item can be one of these: strongly agree; agree; neither agree nor disagree; disagree; and strongly disagree. For each item a score was given ranging from 
5 for strongly agree to 1 for strongly disagree. For negatively worded items, namely items number 2, 5, 8, 11, 14, 18, 22, $28 \& 32$ (see Table 1), the order of scoring was reversed, so that a higher score would be an indicator of higher anxiety (Aida, 1994).

The FLCAS has been used in different studies (Aida, 1994; Elkhafaifi, 2005; Cheng et al., 1999; Horwitz et al., 1986; Matsuda \& Gobel, 2001; Matsuda \& Gobel, 2004; Saito et al., 1999). Among these studies, Horwitz et al. and Aida reported both a high internal reliability and a test-retest reliability of FLCAS.

Considering the validity of the FLCAS, Aida's (1994) factor analysis showed that most of the items had high factor loadings, and only three items related to test anxiety did not load on any of the factors. So we can conclude that this questionnaire is valid in general.

\section{Test Anxiety Scale}

The second questionnaire is called Test Anxiety Scale (TAS) developed by Sarason (1975). The TAS, which is based on the theory and evidence that test anxiety is composed of test-relevant and test-irrelevant thinking, consists of 37 items. The original answers to the questionnaire were dichotomous, but they were changed to a five-point scale $(1=$ completely disagree; 2 = disagree; 3 = neutral; 4 = agree; $5=$ completely agree) by In'nami (2006). He changed the dichotomous scale to a five-point one because, first, as he says five-point scales are interval scales and are more likely to provide normally distributed data. Second, five-point scales increase the accuracy of responses compared to twopoint scales (In'nami, 2006). For the same reasons and also to be consistent with the first questionnaire, we also used the five-point scale. Again for the negatively worded statements, namely items number 3, 15, 26, 27,29 \& 33 (see Table 2), the order of scoring was reversed, and the students with greater anxiety received a higher score (In'nami, 2006).

To investigate the validity of inferences drawn from the TAS, In'nami (2006) analyzed the responses to it first by exploratory factor analysis and then by confirmatory factor analysis. He decided that it is a valid scale.

Both of the above-mentioned questionnaires were translated into Persian. The reason for using the Persian translation of the questionnaires was that the students were chosen from pre-intermediate levels of language proficiency, not advanced levels, and they might not have understood all the items in the questionnaires clearly if they read the original questionnaires. Even if they were chosen from advanced levels, their lack of understanding of one or some of the items of the questionnaires would affect the results. So the questionnaires were translated. Against the common belief that in any translation some meaning is lost, in the opinion of the researchers, the negative effects of translation is less than that of using the original questionnaires because even if there is a mistake in the translation, it affects the responses of all the students in the same way. But the students may understand the original questionnaires in different ways. Moreover, some studies (In'nami, 2006; \& Matsuda \& Gobel, 2004) which used these questionnaires for non-English students also used a translated version. To further reduce the negative effects of translation, the translations of the questionnaires were checked by two M.A. students of English translation at Allameh Tabatabaee University.

Before administering the questionnaires, it was explained to participants that they should answer the items of the first questionnaire (FLCAS) about their feelings and attitudes in their English class and answer the items of the second questionnaire (TAS) about their feelings about an exam which can be any exam, not just their English class final exam. This point was also written on top of the papers. The participants were also asked about their profile information to enable the researcher to obtain their final exam grades later.

3. ILI final exam

The last instrument of this study was ILI's final exam for level Pre 1. Unfortunately, ILI's exam papers are not given or shown to anybody other than the students. So it could not be added to the appendices. Therefore, the only information we can provide about it here is that it consists of 60 multiple choice items divided into four parts: 10 listening comprehension questions, 20 vocabulary questions, 20 grammar questions, and 10 reading comprehension questions.

\section{Procedures and Data Collection}

The questionnaires used in this study were given to the students of Iran Language Institute, at Pre 1 level. Since the regulations of ILI didn't let the researcher administer the questionnaires during the class time, the participants were asked to fill them out at home and bring them back the next session. It was explained to the participants that they were participating in a research study, and that filling out the questionnaires had nothing to do with ILI. Of course, they were told that their final exam grades were necessary for the research. Those students who didn't like their final exam grades to be revealed were excluded from the study.

The questionnaires were administered to eleven classes of female students and one class of male students. The average number of the students in each class was twenty. At the end, 207 completed questionnaires were collected. They were kept aside until the students took their final exam and their grades were announced on the board. Then, according to the names of the students and other information, the grades of the students were obtained and recorded. From these 207 students, the final exam grades of 7 students could not be obtained due to their absence in the final exam session or writing false names on the questionnaires. Accordingly, 200 participants remained in the study.

Finally, the scores of the participants in each questionnaire were calculated once by one researcher and another time by the other according to the method explained in section 4.2. This was done to reduce the possible mistakes of the scorers. Then, the data gathered in this way were analyzed as described below. 


\section{Data Analysis}

In the present study, there were three sets of data: the FLCAS scores, the TAS scores, and the students' final exam grades. Considering descriptive statistics, first the range, mean, mode, and standard deviation of all these sets of data were calculated. Then the skewness and kurtosis of them were also calculated to make sure of the normality of the distribution.

For the FLCAS and the TAS, some descriptive statistics were also offered for each of their items. In fact, for each item, the number of students who had opted for each choice was counted. These statistics help the readers understand which areas of language learning create more anxiety in learners.

The internal reliability of the FLCAS and the TAS were also calculated according to Cronbach's $\alpha$ formula.

The next step was to answer the research questions. As all the research questions were about the relationship between two variables, to answer all of them, a correlation coefficient was calculated by Pearson's formula. The results are presented in Section 5.

\section{RESULTS AND DisCUSSION}

Before trying to answer the research questions, the descriptive statistics of the results are provided. The internal reliabilities of both questionnaires using Cronbach alpha were high ( $\alpha=0.91$ for FLCAS and $\alpha=0.92$ for TAS).

Table 1 shows the number of the students who chose each choice of each item in FLCAS. Table 2 shows the number of the students who chose each choice of each item in the TAS. These two tables are included to provide the reader with more information about the areas which are more anxiety-provoking for the students.

Table 3 summarizes the descriptive statistics of the scores in the two questionnaires and the grades of final exam. As the observed mean in each questionnaire is less than its theoretical midpoint, we can conclude that, generally, the students did not feel very anxious. The skewness and kurtosis of all the variables of this study show that they are normally distributed. In this way, one of the most important assumptions of correlation is met. Therefore, correlation can be used as a means of answering the research questions of this study which will be discussed in the following sections.

TABLE 1.

NUMBER OF THE STUDENTS WHO OPTED FOR EACH CHOICE OF EACH ITEM IN THE FLCAS SA=STRONGLY AGREE, A=AGREE, N=NEITHER AGREE NOR DISAGREE, D=DISAGREE, AND SD=STRONGLY DISAGREE.

\begin{tabular}{|c|c|c|c|c|c|}
\hline Items & SA & $\mathbf{A}$ & $\mathbf{N}$ & D & SD \\
\hline 1. I never feel quite sure of myself when I am speaking in English. & 8 & 30 & 70 & 60 & 32 \\
\hline 2. I don't worry about making mistakes in English class. & 34 & 53 & 44 & 59 & 10 \\
\hline 3. I tremble when I know that I'm going to be called on in English class. & 19 & 36 & 53 & 66 & 26 \\
\hline 4. It frightens me when I don't understand what the teacher is saying in English. & 8 & 54 & 30 & 75 & 33 \\
\hline 5. It wouldn't bother me at all to take more English classes. & 75 & 70 & 19 & 23 & 13 \\
\hline 6. During English class, I find myself thinking about things that have nothing to do with the course. & 1 & 32 & 52 & 74 & 41 \\
\hline 7. I keep thinking that the other students are better at English than I am. & 7 & 45 & 52 & 65 & 31 \\
\hline 8. I am usually at ease during tests in my English class. & 22 & 63 & 65 & 43 & 13 \\
\hline 9. I start to panic when I have to speak without preparation in English class. & 20 & 89 & 33 & 37 & 21 \\
\hline 10. I worry about consequences of failing my English class. & 52 & 52 & 32 & 44 & 20 \\
\hline 11. I don't understand why some people get so upset over English classes. & 33 & 52 & 58 & 44 & 13 \\
\hline 12. In English class, I can get so nervous I forget things I know. & 23 & 54 & 34 & 57 & 32 \\
\hline 13. It embarrasses me to volunteer answers in English class. & 14 & 32 & 35 & 70 & 49 \\
\hline 14. I would not be nervous speaking English with native speakers. & 38 & 62 & 50 & 43 & 7 \\
\hline 15. I get upset when I don't understand what the teacher is correcting. & 6 & 50 & 37 & 71 & 36 \\
\hline 16. Even if I am well prepared for English class, I feel anxious about it. & 7 & 23 & 25 & 63 & 82 \\
\hline 17. I often feel like not going to my English class. & 13 & 69 & 32 & 41 & 45 \\
\hline 18. I feel confident when I speak in my English class. & 32 & 79 & 62 & 25 & 2 \\
\hline 19. I am afraid that my English teacher is ready to correct every mistake I make. & 7 & 40 & 44 & 74 & 35 \\
\hline 20. I can feel my heart pounding when I am going to be called on in my English class. & 45 & 63 & 41 & 33 & 18 \\
\hline 21. The more I study for an English test, the more confused I get. & 6 & 14 & 17 & 83 & 80 \\
\hline 22. I don't feel pressure to prepare very well for English class. & 6 & 15 & 26 & 83 & 70 \\
\hline 23. I always feel that the other students speak English better than I do. & 8 & 33 & 67 & 59 & 33 \\
\hline 24. I feel very self-conscious about speaking English in front of other students. & 4 & 27 & 46 & 83 & 40 \\
\hline 25. English class moves so quickly I worry about getting left behind. & 8 & 21 & 30 & 93 & 48 \\
\hline 26. I feel more tense and nervous in my English class than in my other classes. & 6 & 30 & 29 & 76 & 69 \\
\hline 27. I get nervous and confused when I am speaking in my English class. & 4 & 17 & 41 & 88 & 50 \\
\hline 28. When I am on my way to English class, I feel very sure and relaxed. & 33 & 74 & 66 & 35 & 2 \\
\hline 29. I get nervous when I don't understand every word the English teacher says. & 5 & 40 & 45 & 75 & 35 \\
\hline 30. I feel overwhelmed by the number of rules you have to learn to speak English. & 8 & 35 & 39 & 78 & 40 \\
\hline 31. I am afraid that the other students will laugh at me when I speak English. & 15 & 31 & 38 & 66 & 50 \\
\hline 32. I would probably feel comfortable around the native speakers of English. & 35 & 71 & 58 & 33 & 3 \\
\hline 33. I get nervous when the English teacher ask questions which I haven't prepared in ac & 11 & 67 & 47 & 52 & 33 \\
\hline
\end{tabular}


TABLE 2.

NUMBER OF THE STUDENTS WHO OPTED FOR EACH CHOICE OF EACH ITEM IN THE TAS SA=STRONGLY AGREE, A=AGREE, N=NEITHER AGREE NOR DISAGREE, D=DISAGREE, AND SD=STRONGLY DISAGREE.

\begin{tabular}{|c|c|c|c|c|c|}
\hline Items & SA & $\mathbf{A}$ & $\mathbf{N}$ & D & SD \\
\hline 1. I find myself thinking of how much brighter the other students are than I am. & 7 & 28 & 50 & 66 & 49 \\
\hline 2. If I were to take an intelligence test, I would worry a great deal before taking it. & 8 & 32 & 30 & 76 & 54 \\
\hline 3. If I knew I was going to take an intelligence test, I would feel confident and relaxed, beforehand. & 31 & 81 & 53 & 29 & 6 \\
\hline 4. While taking an important examination I perspire a great deal. & 15 & 28 & 20 & 78 & 59 \\
\hline 5. During course examination I find myself thinking of things unrelated to the actual course material. & 7 & 20 & 35 & 88 & 50 \\
\hline 6. I get to feel very panicky when I have to take a surprise exam. & 25 & 75 & 49 & 30 & 21 \\
\hline 7. During tests I find myself thinking of the consequences of failing. & 21 & 47 & 31 & 64 & 37 \\
\hline 8. After important tests I am frequently so tense that my stomach gets upset. & 10 & 9 & 18 & 71 & 92 \\
\hline 9. I freeze up on things like intelligence tests and final exams. & 4 & 29 & 40 & 77 & 50 \\
\hline 10. Getting a good grade on one test does not seem to increase my confidence on the second. & 17 & 20 & 13 & 75 & 75 \\
\hline 11. I sometimes feel my heart beating very fast during important tests. & 33 & 69 & 28 & 45 & 25 \\
\hline 12. After taking a test I always feel I could have done better than I actually did. & 38 & 90 & 38 & 28 & 6 \\
\hline 13. I usually get depressed after taking a test. & 4 & 22 & 47 & 82 & 45 \\
\hline 14. I have an uneasy, upset feeling before taking a final examination. & 33 & 67 & 35 & 44 & 21 \\
\hline 15. When taking a test my emotional feelings do not interfere with my performance. & 21 & 66 & 64 & 51 & 8 \\
\hline 16. During a course examination I frequently get so nervous that I forget facts I really know. & 7 & 28 & 47 & 68 & 50 \\
\hline 17. I seem to defeat myself while working on important tests. & 5 & 11 & 33 & 93 & 68 \\
\hline 18. The harder I work at taking a test or studying for one, the more confused I get. & 2 & 18 & 20 & 95 & 65 \\
\hline 19. As soon as an exam is over I try to stop worrying about it, but I just cannot. & 23 & 66 & 32 & 66 & 23 \\
\hline 20. During exams I sometimes wonder if I'll ever get through college. & 16 & 26 & 46 & 62 & 50 \\
\hline 21.I would rather write a paper than take an examination for my grade in a course; & 16 & 47 & 45 & 67 & 30 \\
\hline 22. I wish examinations did not bother me so much. & 30 & 49 & 41 & 50 & 30 \\
\hline $\begin{array}{l}\text { 23. I think I could do much better on tests if I could take them alone and not feel pressured by a time } \\
\text { limit. }\end{array}$ & 46 & 46 & 40 & 36 & 32 \\
\hline $\begin{array}{l}\text { 24. Thinking about the grade I may get in a course interferes with my studying and my performance } \\
\text { on tests. }\end{array}$ & 13 & 56 & 48 & 64 & 19 \\
\hline 25. If examinations could be done away with I think I would actually learn more. & 27 & 23 & 38 & 67 & 45 \\
\hline 26. On exams I take the attitude "If I do not know it now there's no point worrying about it." & 20 & 51 & 53 & 52 & 24 \\
\hline 27. I really do not see why some people get so upset about tests. & 38 & 45 & 59 & 45 & 13 \\
\hline 28. Thoughts of doing poorly interfere with my performance on tests. & 26 & 67 & 35 & 56 & 16 \\
\hline 29. I do not study any harder for final exams than for the rest of my course work. & 12 & 23 & 30 & 85 & 50 \\
\hline 30. Even when I'm well prepared for a test, I feel very anxious about it. & 14 & 35 & 35 & 78 & 38 \\
\hline 31. I do not enjoy eating before an important test. & 20 & 41 & 26 & 71 & 42 \\
\hline 32. Before an important examination I find my hands or arms trembling. & 26 & 30 & 32 & 72 & 40 \\
\hline 33. I seldom feel the need for "cramming" before an exam. & 10 & 43 & 59 & 59 & 29 \\
\hline $\begin{array}{l}\text { 34. The university ought to recognize that some students are more nervous than others about tests and } \\
\text { that this affects their performance. }\end{array}$ & 40 & 93 & 51 & 11 & 5 \\
\hline 35. It seems to me that examination periods ought not to be made the tense situations which they are. & 59 & 91 & 35 & 13 & 2 \\
\hline 36. I start feeling very uneasy just before getting a test paper back. & 17 & 39 & 31 & 75 & 38 \\
\hline 37. I dread courses where the professors have the habit of giving "pop" quizzes. & 38 & 52 & 57 & 31 & 22 \\
\hline
\end{tabular}

TABLE 3.

DESCRIPTIVE STATISTICS OF FLCAS SCORES, TAS SCORES, AND FINAL EXAM GRADES

\begin{tabular}{|l|l|l|l|l|l|l|l|}
\hline Variables & Theoretical range & Min-Max & Mean & Mode & SD & Skewness & Kurtosis \\
\hline FLCAS Scores & $33-165$ & $42-135$ & 86.71 & 91 & 19.92 & .182 & .256 \\
\hline TAS Scores & $37-185$ & $51-153$ & 103.05 & $93-110$ & 21.46 & .109 \\
\hline Exam Grades & $0-100$ & $25-99$ & 73.6 & 80 & 11.84 & -.025 & .300 \\
\hline
\end{tabular}

\section{A. Language Anxiety and Foreign Language Test Performance}

To answer the first research question, investigating the relationship between foreign language anxiety and foreign language test performance, the correlation coefficient of FLCAS scores and final exam grades was calculated according to Pearson formula. The results showed that these two variables had a negative relationship $(r=-0.22)$ which is statistically significant at $\mathrm{p}<0.01$.

The negative relationship between language anxiety and test performance is consistent with most of the previous studies. Although some scholars reported facilitative anxiety in language learning context (Baily, 1983; MacIntyre \& Gardner, 1994; Tobias, 1986), much of the data is in favor of debilitative anxiety (Aida, 1994; Elkhafaifi, 2005; Gardner, Tremblay, \& Masgoret, 1997; MacIntyre \& Gardner, 1989; MacIntyre et al., 1997; Mills et al., 2006; Philips, 1992; Young, 1986).

\section{B. Test Anxiety and Foreign Language Test Performance}

To address the second research question, which deals with the relationship between test anxiety and foreign language test performance, the correlation coefficient between TAS score and final exam grades was calculated. This correlation was negative $(r=-0.18)$ and was statistically significant at $\mathrm{p}<0.01$. 
Considering test anxiety, the previous studies revealed contrasting results. Some of them reported a negative relationship between test anxiety and test performance (Chastain, 1975; Horwitz, 1986), in some of them there was no significant relationship between them (In'nami, 2006), yet in some others the relationship was positive (Chastain, 1975). Therefore, rejecting the second null hypotheses of the present study is inconsistent with the existing literature. The possible explanations of this discrepancy are offered below.

Matsuda and Gobel (2004) expressed concern about the results of their study and said that the results should be interpreted with caution because although the students were told to answer about the English classes in general, they may have responded based on the specific class they were attending at that time. A similar problem concerns us here. That is, although the students were told orally to answer TAS based on tests of any subjects in general, which was also written on the top of the questionnaire, they may have responded based on an English class test. The researchers tried to remove this problem by reminding the students of this point, but we could by no means make sure of what was going on in the mind of the students as they responded to the questionnaire. Therefore, the negative relationship between test anxiety and test performance and the positive relationship between test anxiety and language anxiety might be because the students have answered TAS according to their feelings in a foreign language test situation only.

To explain the lack of any relationship between test anxiety and test performance in his study, In'nami (2006) referred to the stakes of the tests, or the degree to which test outcomes affect test-takers' future. In'nami (2006) said that in his study, the listening test had low stakes, and this was one of the reasons why there was no significant relationship between test anxiety and test performance. However, in the present study, the test was relatively high-stakes because if the students failed it, they could not go to a higher level and it cost a lot of time and money for them. It can be one of the reasons for negative relationship between test anxiety and test performance in the present study.

\section{Language Anxiety and Test Anxiety}

In the third research question, we asked whether there was a relationship between foreign language anxiety and test anxiety. In other words, we wanted to see whether a highly anxious person in language classroom is anxious in test situations as well or vice versa. To address this question, the correlation coefficient between the scores obtained in FLCAS and TAS was calculated. There was a strong positive relationship between these two kinds of anxiety ( $r=0.69)$ which was statistically significant at $\mathrm{p}<0.01$.

Previous research suggested that test anxiety was not related to language anxiety (Aida, 1994; MacIntyre \& Gardner, 1989; Matsuda \& Gobel, 2004). So our results are again in contrast with existing literature.

The reason for discrepancy between the results of the present research and other studies considering the relationship between test anxiety and language anxiety might be the fact that other studies conducted factor analysis on FLCAS. These studies were based on Horwitz et al's (1986) claim that one of the components of language anxiety is test anxiety and some of the items in FLCAS measure test anxiety. The previous studies conducted factor analysis on these items and found low factor loadings in them. The difference between results of this study and those of others may be due to using different statistical procedures (factor analysis vs. correlation coefficient) and different number of items measuring test anxiety (about 5 items in FLCAS vs. 37 items of TAS).

Considering the contrasting results about the role of test anxiety in language learning, it seems that more research in this area is needed.

The correlation coefficients of different variables in this study are summarized in Table 4.

TABLE 4.

CORRELATION COEFFICIENTS BETWEEN DIFFERENT VARIABLES OF THIS STUDY

\begin{tabular}{|l|l|l|l|}
\hline Correlation Coefficient & FLCAS Scores & TAS Scores & Exam Grades \\
\hline FLCAS Scores & - & .69 & -.22 \\
\hline TAS Scores & & - & -.18 \\
\hline
\end{tabular}

\section{CONCLUSIONS AND IMPLICATIONS}

Before drawing any conclusion, some points should be noted. Due to its correlational design, this study is by no means perfect. In fact, isolating only two variables from language learning context and calculating correlations between them is unrealistic to some extent because in the real world many factors affect each other. But due to the difficulties that the researchers faced, investigating other factors at the same time was not possible. Therefore, the following conclusions are offered while admitting their shortcomings.

The findings of this study reveal that both language anxiety and test anxiety have a debilitative role in language learning, at least in settings similar to those in this study. This study also shows that language anxiety and test anxiety are related to each other. It means that the students with high language anxiety tend to have high test anxiety too and vice versa. It implies that trying to reduce one type of anxiety will automatically reduce the other type to some extent.

Considering the debilitative role of language anxiety and test anxiety in language classes, we should take measures to reduce both types of anxiety. Participants of Williams and Andrade (2008) attributed their language anxiety to language teachers and other people. Therefore, teachers can be very influential in reducing learners' anxiety. Teachers need to 
reduce anxiety and enhance self-confidence by encouraging students' involvement in classroom activities and creating a comfortable atmosphere (Matsuda \& Gobel, 2004).

Matsuda and Gobel (2004) say that using various activities such as pair work, small group work, games, and role plays may enhance class atmosphere because students feel more comfortable about speaking with a small number of people than confronting the whole class. Teachers should start with pair work and giving the students enough practice and training and then gradually change to a more challenging pattern such as group work and class work.

The participants of Hurd's (2007) study mentioned some strategies to reduce their anxiety. Language teachers can remind students to use these strategies including: actively encouraging yourself to take risks in language learning, such as guessing meanings or trying to speak, even though you might make some mistakes; using positive self-talk; imagining that when you're speaking in front of others, it is just a friendly informal chat; using relaxation techniques; sharing your worries with other students; letting your tutor know you're anxious; give yourself a reward or treat when you do well; being aware of physical signs of stress that might affect your language learning; telling yourself when you speak that it will not take too long; and writing down your feelings in a diary or notebook.

Explicit training in affective strategies can also help students manage anxiety related to language learning and testing. Research suggests that when students are informed about the use, monitoring, and evaluation of specific strategies, performance improves (Oxford \& Crookall, 1989). Furthermore, trained students use a wider variety of strategies and are less likely to become bogged down with ineffective study habits that produce poor results and, hence, anxiety related to tests. Finally, certain types of tests encourage students' participation without creating undue stress for learners. Cooperative efforts reduce the competitiveness that can raise anxiety and hinder progress (Bailey, 1983). The students usually like evaluations that involve partner and small group-work, interviews, problem-solving, and role plays (Young, 1991). These types of evaluations may reduce apprehension (Foss \& Reitzel, 1988). Since evidence indicate that familiar tasks tend to create less anxiety (Bailey, 1983), adequate opportunity to practice the types of tasks to be tested will also create confidence in language learners and reduce the anxiety as a result. Moreover, frequent testing will both familiarize the students with the evaluation procedure and reduce the anxiety in them.

Considering test anxiety, Phillips (1992) offers the following suggestions: First, the teachers should discuss directly the issue of language anxiety with the students because it reassures them that these feelings are normal and anticipated by the teacher. Realizing that the teacher or evaluator understands their feelings reduces at least a part of the tension associated with assessment. Second, the teachers should discuss the nature of language learning because it relieves the students of some of the anxiety-provoking misconceptions. It is important that the students have realistic expectations related particularly to accuracy. Realistic expectations include the understanding that language learning is a lengthy procedure and that errors are a natural part of that process.

Bensoussan (2012) has focused specifically on reducing test anxiety in language classrooms. The participants of this study reported that they would like teachers to make two additions to the course: adding bonus exercises for extra points and giving more practice tests. Joy (2013) also gives the following suggestions for reducing test anxiety in particular: replacing numerical test scores by grading system, and allowing student involvement in test development. According to Joy, both teachers and policy makers can help reduce the students' test anxiety.

To sum up, this study showed that both language anxiety and test anxiety were negatively related to foreign language test performance. Therefore, both teachers and students themselves should take measures to reduce both types of anxiety to achieve better test scores in foreign language classes.

\section{REFERENCES}

[1] Aida, Y. (1994). Examination of Horwitz, Horwitz and Cope's construct of foreign language anxiety: The case of students of Japanese. The Modern Language Journal. 78, 2, 155-68.

[2] Awan, R. N., Azher, M., Anwar, M. N., \& Naz, A. (2010). An investigation of foreign language classroom anxiety and its relationship with students' achievement. Journal of College Teaching and Learning. 7, 11, 33-40.

[3] Bailey, K. M. (1983). Competitiveness and anxiety in adult second language learning: Looking at and through the diary studies. In H. W. Seliger \& M. H. Long (Eds), Classroom oriented research in second language acquisition (pp. 67-102). Rowly, MA: Newbury House.

[4] Bensoussan, M. (2012). Alleviating test anxiety for students of advanced reading comprehension. RELC Journal. 43, $203-216$.

[5] Brown, H. D. (2000). Principles of language learning and teaching (4 ${ }^{\text {th }}$ ed.). New York: Pearson Education.

[6] Chastain, K. (1975). Affective and ability factors in second-language acquisition. Language Learning. 25, 1, $153-61$.

[7] Cheng, Y., Horwitz, E. K., \& Schallert, D. L. (1999). Language anxiety: Differentiating writing and speaking components. Language Learning. 49, 3,417-46.

[8] Dewaele, J. M., Petrides, K. V., \& Furnham, A. (2008). Effects of trait emotional intelligence and sociobiographical variable s on communicative anxiety and foreign language anxiety among adult multilinguals: A review and empirical investigation. Language Learning. 58, 4, 911-960.

[9] Elkhafaifi, H. (2005). Listening comprehension and anxiety in the Arabic language classroom, The Modern Language Journal. 89, 2, 206-20.

[10] Foss, K. A., \& Reitzel, A. C. (1988). A relational model for managing second language anxiety. TESOL Quarterly. 22, 3, 47354.

[11] Gardner, R. C. (1985). Social psychology and second language learning: The role of attitudes and motivation. London: Edward Arnold. 
[12] Gardner, R. C., Tremblay, P. F., \& Masgoret, A. (1997). Towards a full model of second language learning: An empirical investigation. The Modern Language Journal. 81, 3, 344-62.

[13] Horwitz, E. K. (1986). Preliminary evidence for the reliability and validity of a Foreign Language Anxiety Scale. TESOL Quarterly, 20, 4, 559-64.

[14] Horwitz, E. K. (1990). Attending to the affective domain in the foreign language classroom. In S. S. Magnan (Ed), Shifting the instructional focus to the learner (pp. 15-33). Middlebury, VT.

[15] Horwitz, E. K. (2010). Foreign and second language anxiety. Language Teaching. 43, 2, 154-167.

[16] Horwitz, E. K., Horwitz, M. B., \& Cope, J. A. (1986). Foreign language classroom anxiety. The Modern Language Journal. 70 , $2,125-132$.

[17] Hurd, S. (2007). Anxiety and non-anxiety in a distance language learning environment: The distance factor as a modifying influence. System. 35, 4, 487-508.

[18] In'nami, Y. (2006). The effects of test anxiety on listening test performance. System. 34, 3, 317-40.

[19] Joy, J. L. (2013). The altitude of test anxiety among second language learners. Language Testing in Asia. 3, 1-10.

[20] Kleinmann, H. H. (1977). Avoidance behavior in adult second language acquisition. Language Learning. 27, 1, 93-107.

[21] Liu, M., \& Jackson, J. (2008). An exploration of Chinese EFL learners' unwillingness to communicate and foreign language anxiety. The Modern Language Journal. 92, 1, 71-86.

[22] MacIntyre, P. D. (1995). How does anxiety affect second language learning? A reply to Sparks and Ganschow. The Modern Language Journal. 79, 1, 90-99.

[23] MacIntyre, P. D., \& Gardner, R. C. (1989). Anxiety and second language learning: Toward a theoretical clarification. Language Learning. 39, 2, 251-75.

[24] MacIntyre, P. D., \& Gardner, R. C. (1991). Methods and results in the study of anxiety and language learning: A review of the literature. Language Learning. 41, 1, 85-117.

[25] MacIntyre, P. D., \& Gardner, R. C. (1994). The subtle effects of language anxiety on cognitive processing in the second language. Language Learning. 44, 2, 283-305.

[26] MacIntyre, P. D., Noels, K. A., \& Clement, R. (1997). Biases in self-ratings of second language proficiency: The role of language anxiety. Language Learning. 47, 2, 256-87.

[27] Marcos-Llinás, M. \& Garau, M. J. (2009). Effects of language anxiety on three proficiency-level courses of Spanish as a foreign language. Foreign Language Annals. 42, 1, 94-111.

[28] Matsuda, S., \& Gobel, P. (2001). Quiet apprehension: Reading and classroom anxieties. JALT Journal. 23, $227-74$.

[29] Matsuda, S., \& Gobel, P. (2004). Anxiety and predictors of performance in the foreign language classroom. System. 32, 1, 2136.

[30] McCroskey J.C. (1970). Measures of communication-bound anxiety. Speech Monographs. 37, 269-77.

[31] Mills, N., Pajares, F., \& Herron, C. (2006). A reevaluation of the role of anxiety: Self-efficacy, anxiety, and their relation to reading and listening proficiency. Foreign Language Annals. 39, 2, $276-95$.

[32] Oxford, R. L., \& Crookall D. (1989). Research on language learning strategies: Methods, findings, and instructional issues. Modern Language Journal. 73, 3, 404-19.

[33] Oxford, R. L., \& Ehrman, M. E. (1995). Adults language learning strategies in an intensive foreign language program in the United States. System. 23, 3, 359-86.

[34] Phillips, E. (1992). The effects of language anxiety on students' oral test performance and attitudes. The Modern Language Journal. 76, 1, 14-26.

[35] Saito, Y., Garza, T., \& Horwitz, E. (1999). Foreign language reading anxiety. The Modern Language Journal. 83, 2 , 202-18.

[36] Sarason, I.G. (1975). The Test Anxiety Scale: Concept and research. In I.G. Sarason \& C.D. Spielberger (Eds). Stress and Anxiety (pp. 193-217). Washington, DC: Hemisphere.

[37] Sarason, I. G. (1978). The Test Anxiety Scale: Concept and research. In C.D. Spielberger \& I.G. Sarason (Eds). Series in clinical and community psychology (pp. 193-216). Washington: Hemisphere Publishing Corporation.

[38] Sieber, J. E. (1980). Defining test anxiety: Problems and approaches. In I. G. Sarason (Ed). Test anxiety: Theory, research and applications (pp. 15-42). Hillsdale, NJ: Lawrence Erlbaum Associates.

[39] Steinberg, F. S., \& Horwitz, E. K. (1986). The effect of induced anxiety on the denotative and interpretative content of the second language speech. TESOL Quarterly. 20, 1, 131-136.

[40] Tobias, S. (1986). Anxiety and cognitive processing of instruction. In R. Schuwartzer (Ed), Self-related cognition in anxiety and motivation (pp. 35-54). Hillsdale, NJ: Erlbaum.

[41] Watson, D., \& Friend R. (1969). Measurement of social-evaluative anxiety. Journal of Consulting and Clinical Psychology. 33, 448-57.

[42] Williams, K. E., \& Andrade, M. R. (2008). Foreign language learning anxiety in Japanese EFL university classes: Causes, coping, and locus of control. Electronic Journal of Foreign Language Teaching. 5, 2, 181-191.

[43] Young, D. (1986). The relationship between anxiety and foreign language oral proficiency ratings. Foreign Language Annals. $19,4,439-45$.

[44] Young, D. (1991). An investigation of the students' perspectives on anxiety and speaking. Foreign Language Annals. 23, 4, 539-53.

[45] Zheng, Y. (2008). Anxiety and second/foreign language learning revisited. Canadian Journal for New scholars in Education. 1, $1,1-12$. 


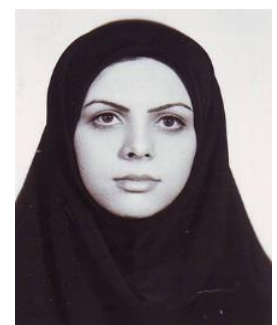

Masoomeh Salehi was born in Shahriar, Iran, on July $4^{\text {th }}$, 1984. She got her B.A. in English translation from Allameh Tabatabaee University, Tehran, Iran, in 2006. She also got her M.A. in TEFL from Allameh Tabatabaee University, Tehran, Iran, in 2009. Now she is a PhD candidate in TEFL at Islamic Azad University, Shiraz Branch, Shiraz, Iran.

She has worked as an EFL Instructor at Shahed University and Payam-e-Noor University. Currently, she is a Faculty Member at Islamic Azad University, Shahr-e-Qods Branch, Tehran Province, Iran. Previously, she has published two articles and has one article in press. Her current area of research interest is testing.

Fahimeh Marefat is an associate professor at Allameh Tabatabaee University. Her area of interest includes writing issues and research methods. 